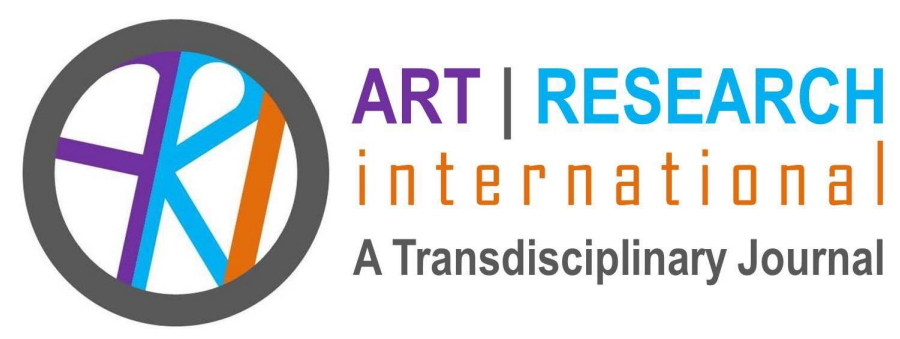

\title{
WHAT CAN ART DO? A REVIEW OF BRIDGING COMMUNITIES THROUGH SOCIALLY ENGAGED ART EDITED BY ALICE WEXLER AND VIDA SABBAGHI
}

\section{Kristin Bergaust Oslo Metropolitan University kribe@oslomet.no}

Kristin Bergaust is educated at the University of Oslo and at the National Academy of Fine Art in Oslo. She works as an artist, researcher and educator. She is a full professor at the Faculty of Technology, Art and Design at Oslo Metropolitan University, since 2008. She was formerly professor and head of Intermedia at Trondheim Academy of Fine Arts, NTNU (2001-2008) and artistic director of Atelier Nord media lab for artists (1997-2001). Kristin is one of the pioneers of the self-organized early media art scene in Norway in the 1990s. Her feminist and relational perspectives are shaped through performative and technological strategies, sometimes fed by cultural history or other narratives. Experiments with the communicative and the sensory are inherent both in her research and art. Currently, she engages in ecological and transcultural processes in urban contexts through artistic methods, interdisciplinary research and technological developments.

Abstract: My review of Bridging Communities Through Socially Engaged Art (2019), looks at this collection of case-studies and practical examples, mainly from the United States, read by a Northern-European reviewer. The book presents twenty-seven inspiring project examples from artistic practice, art education, art dissemination and art therapy. This review looks at some chapters, representing different sections of the book: Museums and Cultural Institutions in Diverse Communities, Art Pedagogy in Diverse Communities, Critical Race and Gender Perspectives, and DIS/ability Justice and Outsiders. The included chapters of the volume are mainly authored by practicing professionals and offer both concrete descriptions and reflections. The dire situation of charged political and contextual conditions 
was a sub-text in my reading. As a conclusion, I found this book a rewarding and inspirational experience to be recommended for students and decision-makers.

Keywords: socially engaged art; art education; art therapy; community art work 
This book of twenty-seven short to medium-length essays offers an overview of socially engaged art: artistic practices, art education, as well as institutional projects, and artist run initiatives working with communities. Although quite culturally diverse, the contributions all originate from US-based writers, professionals, artists and activists from the fields of contemporary art, art education, museum education, art therapy, art history and disability studies within art education. Many authors are affiliated with academic institutions, which should be expected of a book that is a development of material from the regional conference of USSEA/InSEA, An Inclusive World: Bridging Communities held at Queens Museum, New York in 2015.

The essays are divided into four sections: Museums and Cultural Institutions in Diverse Communities, Art Pedagogy in Diverse Communities, Critical Race and Gender Perspectives, and DIS/ability Justice and Outsiders. Reading as an artist and educator with European perspectives and reference points, not all of the described institutional or educational contexts are immediately accessible to me. Even so, the themes and ideas brought forward seem timely and important for a European context also. Looking at the United States from the outside, and the impact of "Trump," it seems there is a dire need to bridge communities, create dialogue and promote social justice. The editors, without mentioning explicitly the current political context, set out to "seek innovative, re-envisioned approaches to the arts in education and society." (Wexler \& Sabbaghi, 2019, p. 9).

This book is a treasure trove of stimulating information for students and practising teaching artists and anyone else engaged in the field. Every time I dove into it, I found something new, and invitations to look more closely. There are many inspiring descriptions of concrete projects that encourage participation and dialogue in museums and institutions and pedagogical projects in schools and in other social situations. One chapter that stood out for me is "Strength in Diversity: In the Galleries with English Language Learners" by Patricia Lannes, April Oswald, Heather Maxon and Marianna Pegno. This chapter powerfully describes four inclusive projects in established art institutions with refugees and immigrants. The methods and strategies used, such as art-making, visual literacy, and community collaborations, clearly demonstrate how art and art education are fostering self-expression, the development of language skills and understandings of cultures and communities, all of which again, stimulate a sense of empowerment. Readers are given enough information to get a sense of this meaningful and important work. If I miss something from this chapter, it would be some accounts of what did not work and identification of some of the challenges experienced. One of the authors, Patricia Lannes, takes a more general critical position. She makes me curious when she writes: "A paradigm shift where cultural institutions have a responsibility to engage community members is necessary if we believe in the value of cultural experiences and in the individual right to equal access to meaningful aesthetic encounters" (Lannes, Oswald, Maxon \& Pegno, 2019, p. 23). Pointing to power structures, hierarchies and professional attitudes in institutions that might create obstacles, are essential qualities in material that might be read by students and used as inspiration and 
references for new projects. I see the importance of documenting the usefulness of this work to motivate further work, as well as to elicit support from funding bodies and decision makers.

The chapter "From Please Touch to Art Access" by Mitra Dekameh and Vida Sabbaghi (2019, p. 57-66), formulates a theoretical foundation for how they work, by going back to the concept of rhizome coined and developed by Deleuze and Guattari (1987) in the 1980s. In practice, they pose the notions of learning from and connecting and becoming with as philosophical principles they work from, while concepts such as inclusion and outreach are less relevant to their thinking. Their target groups included young people with autism, people diagnosed with Alzheimer's and a range of participants with challenging mental conditions together with their caregivers and families. A critical perspective on institutional power structures and imbalances is crucial. In addition, I found in this conceptual discussion, some important principles to develop problem-solving and critical assessment of work. By employing the rhizomatic thinking as a way of mapping their collaborations with diverse communities, the project ArtAccess seemed to have found flexible ways of creating mutual engagement and dialogue. Underscoring the rhizomatic character of multiple entry points, the program combines artistic practice and art therapy.

Bridging Communities also delivers very interesting accounts of pioneering projects instigated by individual artists. Martha Wilson tells the story of her own practice connected to the Franklin's Furnace since 1976, showing how experimental artistic concerns and artists' sensitivity to societal and cultural discourses have been disseminated through text, performance, or virtual strategies online. These practices are not necessarily seen or given attention from the established art institutions, but are promoted by artists where they live and work. Another account of historical interest and a rendering of a very productive pedagogic and artistic process is "How do you get to Prospect Avenue?" by Tim Rollins. The artist started teaching art in the early 1980s to underprivileged youth in public schools in South Bronx with minimal resources and facing structural resistance. Over time, he developed K.O.S (Kids of Survival), which also entered the art world by creating successful gallery exhibitions, which in turn opened possibilities for students to access further education and commence careers as artists. Rollins rightly remarks that self-satisfaction and congratulation is not enough, and points towards art as a pedagogically powerful means of acquiring general knowledge, rather than simply being a recreational activity.

Race and gender are thoroughly debated in a separate section of the book. In the chapter "\#Blacklivesmatter," Alice Wexler, from the perspective of a white educator and researcher, discusses race by employing a critical discussion of cultural appropriation. Coco Fusco's analysis of certain forms of cultural appropriation is cited, as this is also "about reckoning with a history of colonialist power relations vis-a-vis non-Western cultures and peoples to contextualize certain forms of appropriation as symbolic violence" (Fusco ,1999, p. 66 cited in Wexler, 2019, p. 148). The artists Scott (2014) and Pope.L (2002) are used as 
examples, as according to Wexler, they deliver counter-appropriated work. She suggests that performance art can make direct inroads to our unconscious constructions of and assumptions of racial identity.

Following this, in "Bridging Racial Divides, through Interracial Dialogue in Art/ Education," Wanda B. Knight's chapter (2019), offers an overview of how a racially divided society has implications for education, teaching and learning. From her position as a female professor of color, she discusses her work with racial identity development through the pedagogical tools of dialogue and mapping. Her goal is to provide practical and useful examples of how art education pedagogy potentially can bridge the racial divides that stem from inequities and injustices in education.

Among several projects that are localized in specific environments, Cindy Maguire and Rob McCallum ArtsAction Group works in "global partnerships with populations in conflict-affected environments" (2019, p. 38). In their chapter "ArtsActionGroup Fostering Capabilities through Socially Engaged Art," they give a rigorous overview of their theoretical framework, both the pedagogical and art thinking that underpin their strategy of co-designing their workshops with local partners. Storytelling through different means and media is their chosen method to help both individual and collective sharing and dealing with trauma and experiences in diverse circumstances in Sri Lanka, Kosovo and Algeria.

The last section of the book, DIS/ability Justice and Outsiders is relatively less rich than the other parts, with only three contributions that are very different in theme and scope. Kenny Hill's project Chauvin Sculpture Garden is described by the art historian Christina McCollum. Relatively little is known about Hill's ideas and the symbolism embedded in his iconography of angels and self-portraits, but the author has collected much information from neighbours and collaborators through personal communication. Even so, I am left unsure of how to understand this phenomenon within the framework of this book. How is this a socially engaged art project? The author touches upon the ethics of displaying and preserving something that might not be meant for the gaze of tourists, let alone the public displays of personal belongings and photographs left by Hill when he was evicted in the year 2000. There are also mentions of this being a project that has ecological aspects, since it implies reclaiming land from the bayou, and can be said to be a perspective on resilience. Fascinating as this project seems to be, the discussions around it should be developed, especially since this estate is now run by a university.

In "All Our Voices Developing Frameworks for Inclusive Research in Art Education," Flavia M.C. Bastos presents and reflects on the research of Samantha Johnson Charek. Here the ethics and actual methods for including artists of disabilities are discussed in more depth, looking at how to develop research methods and environments that can accomplish this. It seems this field is in many ways immature and in need of further work, but here the reader is given more questions to process and think through. The terms used, such as 
outsider art, for instance, are concepts of which I am cautious. What does it create in further discourse to label artistic practice as outside?

Across this book there are a variety of valuable accounts, far from all are discussed here. The strength of the collection is the concrete descriptions of project methods, contexts and circumstances. Many chapters illuminate the critical and theoretical perspectives informing the works and projects, and all in all there is much food for thought and discussion in environments where art education, participatory art and socially engaged art are practiced and tried out.

The importance of the autonomous as a framework and condition for art has been pointed out throughout modernism and is still at work in present-day art institutions. The idea of the autonomous position of art as something different from knowledge, morals and religion, an aesthetic experience or reflection that was not utilitarian, stems from Immanuel Kant's famous Critique of Judgment (1790/1914), and has influenced thinkers and artists throughout history. Today contemporary art tends to be reflexive, layered and unpredictable, sometimes difficult to grasp without additional information. These characteristics are qualities that makes art different from, for instance, entertainment, social work or academic production of knowledge.

However, theoretical and practice-based articulations and discussions of participatory or socially engaged art have now matured and developed over the years. Well-known examples of these writings can be found in the French curator and writer Nicolas Bourriaud's (1998) seminal book of essays, Relational Aesthetics, the British art historian Claire Bishop's (2004) critique of Bourriaud's work in Antagonism and Relational Aesthetics, and later critical and historical investigations of the participatory, for instance in her book Artificial Hells (Bishop, 2012). Pablo Helguera's (2011) practice-based take on the social in Education for Socially Engaged Art has brought the pedagogical perspectives forward.

Bridging Communities Through Socially Engaged Art is a contribution to this discourse by focusing so directly on concrete examples. In doing so, there is a risk of becoming self-congratulatory, too sure of representing what is best practice or having the perfect solutions when art is put to work in societal contexts. I am happy to say that this collection of examples of what art, art pedagogy, art therapy and art dissemination contribute in society, generally avoids such pitfalls. The many examples and reflections written by people who actually did the projects themselves, manage to inspire an interested reader with a professional background in art. I imagine decisionmakers and professionals in other fields might find new understandings of what art can do, a much-needed perspective in a troubled world. 


\section{REFERENCES}

Bastos, F. M. C. (2019). All our voices developing frameworks for inclusive research in art education. In A. Wexler \& V. Sabbaghi (Eds.), Bridging communities through socially engaged art (pp. 224-232). New York: Routledge.

Bishop, C. (2004). Antagonism and relational aesthetics. October Magazine, (110), 51-79. Retrieved from: https://www.mitpressjournals.org/doi/ $\underline{10.1162 / 0162287042379810}$

Bishop, C. (2012). Artificial hells: Participatory art and the politics of spectatorship. London: Verso.

Bourriaud, N. (1998). Relational aesthetics. Paris, FR: Les Presses du Réel.

Dejkameh, M. \& Sabbaghi, V. (2019). From please touch to art access. In A. Wexler \& V. Sabbaghi (Eds.), Bridging communities through socially engaged art (pp. 57-66). New York: Routledge.

Deleuze, G. \& Guattari, F. (1987) A thousand plateaus. Minneapolis, MN: University of Minnesota Press.

Fusco, C. (1999). Passionate irreverence: The cultural politics of identity. In B. Wallis, M. Weems \& P. Yenawine (Eds.), Art matters: How the culture wars changed America (pp. 62-73). New York: New York University Press.

Helguera, P. (2011). Education for socially engaged art. New York: Jorge Pinto. Books.

Kant, I. (1914). Kant's critique of judgement (2nd ed.) (J. H. Bernard, Trans.) London: Macmillan. (Original work published in 1790) Retrieved from: https://oll.libertyfund.org/titles/kant-the-critique-of-judgement

Knight, W. B. (2019). Bridging racial divides, through interracial dialogue in art/education. In A. Wexler \& V. Sabbaghi (Eds.), Bridging communities through socially engaged art (pp. 158-168). New York: Routledge.

Lannes, P., Oswald, A., Maxon, H. \& Pegno, M. (2019). Strength in diversity: In the galleries with English language learners. In A. Wexler \& V. Sabbaghi (Eds.), Bridging communities through socially engaged art (pp. 22-33). New York: Routledge.

Maguire, C. \& McCallum, R. (2019). ArtsActionGroup fostering capabilities through socially engaged art. In A. Wexler \& V. Sabbaghi (Eds.), Bridging communities 
through socially engaged art (pp. 38-47). New York: Routledge.

McCollum, C. (2019). A case study of Kenny Hill's sculpture garden, its preservation and decay. In A. Wexler \& V. Sabbaghi (Eds.), Bridging communities through socially engaged art (pp. 214-223). New York: Routledge.

Pope.L, W. (2002). Bocio. In M. H. Bessire (Ed.), William Pope L.: The friendliest black artist in America (pp. 70-73). New York: New York University Press.

Rollins, T. (2019). How do you get to Prospect Avenue? In A. Wexler \& V. Sabbaghi (Eds.), Bridging communities through socially engaged art (pp.79-89). New York: Routledge.

Scott, D. (2014). "Illegitimate": Dread Scott on the killing of Michael Brown. Sightlines. Retrieved from: https://walkerart.org/magazine/dread-scott-ferguson-michael-brown

Wexler, A. (2019). \#Blacklivesmatter. In A. Wexler \& V. Sabbaghi (Eds.), Bridging communities through socially engaged art (pp. 147- 157). New York: Routledge.

Wexler, A. \& Sabbaghi, V. (Eds.) (2019). Bridging communities through socially engaged art. New York: Routledge.

Wilson, M. (2019). Martha Wilson and Franklin Furnace. Half a century of change as the only constant. In A. Wexler \& V. Sabbaghi (Eds.), Bridging communities through socially engaged art (pp. 13-21). New York: Routledge. 